\title{
REASONS FOR USING INTERCULTURAL COMMUNICATION TRANSFERS AS PERCEIVED BY SIMULTANEOUS INTERPRETERS
}

\author{
Nguyen Ninh Bac* \\ VNU University of Languages and International Studies \\ Pham Van Dong street, Cau Giay district, Hanoi \\ Received 12 October 2020 \\ Revised 10 November 2020; Accepted 17 November 2020
}

\begin{abstract}
This research aimed to understand the possible reasons for the use of intercultural communication (ICC) transfers from the perspective of professional simultaneous interpreters. Based on the ICC transfers suggested by Nguyen Quang (2014), the researcher conducted a focus group interview (FGI) to collect data and analysed it inductively. Seven reasons were found for the use of ICC transfers, categorized into two themes: Enhancing Audience's Comfortability (Theme 1) and Enhancing Interpreter's Comfortability (Theme 2). In general, this means using ICC transfers in particular, having intercultural competence (IC) in general, is beneficial not only to the audience, but also to the interpreters themselves.
\end{abstract}

Keywords: ICC, simultaneous interpreting, competence, FGI.

\section{Introduction}

As a service industry, interpreting is becoming increasingly important in Vietnam in parallel to the country's integration into the global economy. To be competitive in the industry, beside other qualities, an interpreter shall also possess IC. Constituting a part of a doctoral dissertation to explore the IC performed by English - Vietnamese simultaneous interpreters (SIrs) via ICC transfers during their real-life conferences, this article is to answer the research question: "What are the possible reasons for the use of ICC transfers as perceived by SIrs?".

\section{Literature Review - Intercultural Communication Transfers}

This research relied on the list of ICC transfers that Nguyen (2014) recommended to investigate the IC performed by SIrs. Accordingly, four types of ICC transfers were

\footnotetext{
* Tel.: +84904245158

Email: bacvnu@gmail.com
}

put forward, including (i) absolute linguistic transfer, (ii) relative linguistic transfer, (iii) communicative transfer, and (iv) cross-cultural transfer. The priority of all these transfers is to make sure the impact brought to a language A speaker by the source (spoken) text is equally perceived by a language $\mathrm{B}$ audience through the target (spoken) text ${ }^{1}$.

In (i), linguistic factors of language $\mathrm{A}$ is rendered in a one-to-one manner to language B, for example (Nguyen, 2014):

Source text: "We'll talk about it later."

Target text: "Chúng ta sẽ nói về chuyện đó sau." (English back translation: "We will talk about it later.")

Regarding (ii), the source text is manipulated as it is rendered to language B.

\footnotetext{
1 From this point, "text" is implicitly understood as "spoken text" for convenience. Text (including written and spoken texts) is a more conventional term in translation and interpreting studies. That is why in this research, it is used instead of "discourse" or "utterance".
} 
The manipulations could be restructuring, rearrangement of text components, addition and/or omission of text components, and relative alternation. One example of (ii) is:

Source text: "He was reading when I came yesterday".

Target text: "Hôm qua khi tôi đến thì nó đang đọc sách". (English back translation: "Yesterday when I came, he was reading.")

In (iii), the meaning is preserved from the source text while most linguistic factors are changed. Thanks to this change, the target text becomes more acceptable to target audience of language B. Example of (iii):

Source text: "Search me".

Target text: "Hỏi tôi thì hỏi cái đầu gối còn hơn". (English back translation: "If you asked me, it could be better if you asked your knees.")

Finally, the use of (iv) requires a large exposure to both source language (SL) and target language (TL) cultures. It is often deployed for the culture-specific source texts either reflecting cultural practices, being influenced by cultural hiddens, or representing cultural preferences. One example of (iv) is as follows:

Source text: "Honey, it's time for tea".

Target text: "Em ơi, cơm nước thế nào nhỉ? Muộn rồi đấy". (English back translation: "Honey, how is our meal? It's late already.")

For data analysis, the four transfers were coded from S1 to S4. Table 1 below summarizes the description of these strategies.

Table 1: Nguyen's transfers in ICC (2014)

\begin{tabular}{|c|c|c|c|c|}
\hline \multicolumn{2}{|c|}{ Type of transfer } & Method of transfer & Priority & Pragmatic force \\
\hline \multirow[b]{2}{*}{$\begin{array}{l}\text { Linguistic } \\
\text { transfer }\end{array}$} & $\begin{array}{l}\text { S1: Absolute } \\
\text { linguistic } \\
\text { transfer }\end{array}$ & $\begin{array}{l}\text { Language A components } \\
\text { transferred one-to-one to } \\
\text { language B components }\end{array}$ & $\begin{array}{c}\text { Lexical } \\
\text { components }\end{array}$ & $\begin{array}{l}\text { Pragmatic force } \\
\text { on native speaker } \\
\text { of language } \mathrm{A} \text { is } \\
\text { equivalent to that of } \\
\text { language } \mathrm{B}\end{array}$ \\
\hline & $\begin{array}{l}\text { S2: Relative } \\
\text { linguistic } \\
\text { transfer }\end{array}$ & $\begin{array}{c}+ \text { Text restructuring } \\
+ \text { Rearrangement of text } \\
\text { components } \\
+ \text { Addition and/or omission } \\
\text { of text components } \\
+ \text { Relative alternation }\end{array}$ & $\begin{array}{l}\text { Text and } \\
\text { pragmatic } \\
\text { components }\end{array}$ & $\begin{array}{c}\text { Pragmatic force } \\
\text { on native speaker } \\
\text { of language } \mathrm{A} \text { is } \\
\text { equivalent to that of } \\
\text { language } \mathrm{B}\end{array}$ \\
\hline \multicolumn{2}{|c|}{ S3: Communicative transfer } & $\begin{array}{l}\text { + Replacement of linguistic } \\
\text { components } \\
+ \text { Reservation of message } \\
\text { meaning }\end{array}$ & $\begin{array}{l}\text { Discourse } \\
\text { and } \\
\text { pragmatic } \\
\text { components }\end{array}$ & $\begin{array}{l}\text { Pragmatic force on } \\
\text { native speaker of } \\
\text { language } \mathrm{A} \text { is more } \\
\text { or less equivalent to } \\
\text { that of language } \mathrm{B}\end{array}$ \\
\hline S4: Cross- & ultural transfer & $\begin{array}{c}\text { + Transference and reflection } \\
\text { of cultural practices } \\
+ \text { Transference and reflection } \\
\text { of cultural hiddens } \\
+ \text { Transference and reflection } \\
\text { of preferences in categorical } \\
\text { dimensions }\end{array}$ & $\begin{array}{l}\text { Cultural and } \\
\text { pragmatic } \\
\text { components }\end{array}$ & $\begin{array}{l}\text { Pragmatic force on } \\
\text { native speaker of } \\
\text { language } \mathrm{A} \text { is more } \\
\text { or less equivalent to } \\
\text { that of language } \mathrm{B}\end{array}$ \\
\hline
\end{tabular}




\section{Research Method - Focus Group Interview}

Interview, according to Kvale (1996) and Cohen, Manion and Morison (2007), is an activity where at least two people exchange opinions about a topic that they are all interested in. For the purpose of collecting data, interview is a flexible tool that helps the researcher to make use of different sensory channels and codes: verbal and non-verbal, vocal and non-vocal.

Among others, FGI is one type of interview that typically involves five to ten participants (Krueger \& Casey, 2000). The interaction among participants is what makes FGI special and different from one-to-one interview, enabling rich data generation. Participants in an FGI do not need to reach consensus with one another. The views collected are more collective than individual (Cohen et al., 2007, p. 376).

As the whole group focuses on a specific topic, FGI often generates in-depth information that may not be collected in other forms of interview (Cohen et al., 2007). Beside other purposes, FGI is particularly helpful in generating qualitative data quickly and inexpensively. It can be used to complement other methods (Bloor, 2001, p. 17) and triangulate with data collected by other tools, such as other types of interviewing, questionnaire, and observation (Cohen et al., 2007, p. 377).

Naturally, like any other method, FGI owns certain pitfalls. For example, the data collected is often of limited quantification or generalizability, the number of interviewees is often small and therefore may yield less insights than a survey. The interview may be dominated by some people while others do not contribute as much as expected (Cohen, 2007 et al., p. 377).

\section{Research Data}

This research is to supplement the findings of Nguyen (2020), which used a survey to reveal the reactions of the target audience to ICC transfers. In Nguyen (2020), some situations that were inter-culturally difficult to be rendered did not show really clear trends in the audience's reaction. Therefore, FGI was deployed to discover the insights of senior professional SIrs on these points. With this research, ICC transfers are investigated thoroughly from the perspectives of not only the audience but also the interpreters, who are another integral player in an interpreter-mediated event.

In total, eight interpreters were interviewed (coded as I1 to I8 in alphabetical order). While seven are based in Hanoi, one interpreter (I2) is based in Ho Chi Minh City. These interpreters have had from 12 to over 20 years of experience, working in a large variety of areas (diplomatic, education, industry, information technology, health, agriculture, etc.) and settings (small technical seminars, large symposiums, bilateral/ multilateral negotiations, escort events, state head summits, etc.). Seven of them joined the FGI whereas I1 was interviewed individually (for half an hour) due to a last-minute change in his work schedule. Their insightful knowledge of SI was expected to answer the research question.

The group interview lasted for one and a half hours. After considerations, the researcher decided to conduct the FGI online (on Zoom platform at www.zoom.us) for its many advantages, including convenience, connectivity, and user-friendliness (Archibald et al., 2019). With participants' permission, the whole discussion was video and audio recorded for transcription and analysis later using Zoom's record function. Besides, the researcher also used an external voice recorder (Sony P440) as a backup in case there were network interruptions. To ensure that the expected data could be collected while enabling insightful side-discussions, semistructured interview technique was deployed. A detailed agenda with six question items was carefully prepared and piloted before use.

For convenience, the language used in 
the FGI was Vietnamese. When quotes from interviewees are inserted into the analysis below, English translations are provided by the researcher.

\section{Findings and Discussion}

\subsection{Overall Findings.}

Based on the data provided by focus group interviewees (including interviewee I1 who was engaged one-on-one), three major findings were harvested. First, it was demonstrated by all professional interpreters in the interview that they did use ICC transfers, particularly S3 (communicative transfer) and S4 (crosscultural transfer). Even when they do not use ICC transfers, all SIrs explicitly considered intercultural aspects before making the final decision in how to render the source text (e.g. I4, I7, I1 in question 1; I4, I1 in question 2; I4, I6, I7 in question 3; I6, I7, I1 in question 4; I2, I7, I4 in question 5; and I3, I6, I4 in question 6). In other words, IC was important to them and indeed performed by them in authentic workshop situations. This finding reinforces the results of previous works to a certain extent (Hurtado \& Olalla-Soler, 2016; Yarosh, 2015; Kaczmarek, 2010; Eyckmans, 2017; Fenyo, 2005; Dinçkan, 2010; Bahumaid, 2010; and Solovyeva, 2015) on the ownership of cultural/IC by interpreters and translators.

Second, to directly respond to the research question, seven reasons (coded as R1 to R7) under two themes were found and listed in Table 2. In overall, most reasons were recognized by more than one interviewee and/or in more than one FGI question (workshop situation). Three of them gained attention from at least five out of eight FGI participants (R1, R2, R7). The list of these reasons, by all means, is neither exhaustive nor representative due to the limited number of FGI participants and situations. Its meaning is to suggest some reasons that professional practitioners considered when using ICC transfers in real-life.

Table 2: Summary of FGI Results

\begin{tabular}{|c|c|c|c|c|}
\hline Interviewee & Question & Code & Reason & Theme \\
\hline $\mathrm{I} 4, \mathrm{I} 4$ & 1 & 1.1 - Conformity to speaker's & R1 - Accurate & Theme 1 - \\
\hline I8 & 6 & intention & comprehension & Enhancing \\
\hline I1 & 2 & 1.2 - Easy comprehension & & comfortability \\
\hline $\mathrm{I} 1, \mathrm{I} 6, \mathrm{I} 7$ & 1 & & & \\
\hline $\mathrm{I} 2, \mathrm{I} 5$ & 1 & $\begin{array}{l}2.1 \text { - Avoidance of tension due } \\
\text { to political/cultural differences }\end{array}$ & $\begin{array}{l}\text { R2 - Lower } \\
\text { sensitivity }\end{array}$ & \\
\hline $\begin{array}{c}\mathrm{I} 1, \mathrm{I} 2, \mathrm{I} 4, \mathrm{I} 6, \\
\mathrm{I} 7\end{array}$ & 3 & $\begin{array}{l}2.2 \text { - Neutrality/Lower } \\
\text { sensitivity }\end{array}$ & & \\
\hline $\mathrm{I} 2$ & 3 & 2.3 - Higher acceptability & & \\
\hline $\mathrm{I} 1, \mathrm{I} 4$ & 1 & 3.1 - Suitability to Westerners & \multirow{2}{*}{$\begin{array}{l}\text { R3 - Higher } \\
\text { universality }\end{array}$} & \\
\hline $\mathrm{I} 1, \mathrm{I} 7$ & 4 & $\begin{array}{l}3.2 \text { - Universal addressing } \\
\text { method }\end{array}$ & & \\
\hline I1 & 4 & 4.1 - Higher respect & $\begin{array}{l}\text { R4 - Higher } \\
\text { respect }\end{array}$ & \\
\hline I6 & 6 & 5.1 - Higher equality & $\begin{array}{l}\text { R5 - Higher } \\
\text { equality }\end{array}$ & \\
\hline
\end{tabular}




\begin{tabular}{|c|c|c|c|c|}
\hline I6, I7, I8 & 2 & \multirow{3}{*}{$\begin{array}{l}6.1 \text { - Unimportant details } \\
\text { removal }\end{array}$} & \multirow{5}{*}{$\begin{array}{l}\text { R6 - Higher } \\
\text { efficiency }\end{array}$} & \multirow{6}{*}{$\begin{array}{l}\text { Theme } 2 \text { - } \\
\text { Enhancing } \\
\text { interpreter's } \\
\text { comfortability }\end{array}$} \\
\hline $\mathrm{I} 1, \mathrm{I} 2, \mathrm{I} 7, \mathrm{I} 8$ & 5 & & & \\
\hline I1, I3, I6, I8 & 6 & & & \\
\hline $\mathrm{I} 2$ & 5 & \multirow{2}{*}{$\begin{array}{l}6.2 \text { - Saving of time and } \\
\text { resources }\end{array}$} & & \\
\hline I7 & 6 & & & \\
\hline I1 & 3 & $\begin{array}{l}7.1 \text { - Authentic Vietnamese } \\
\text { preservation }\end{array}$ & $\begin{array}{l}\text { R7 - Authentic } \\
\text { Vietnamese } \\
\text { preservation }\end{array}$ & \\
\hline
\end{tabular}

Third, as seen in Table 2, the seven reasons recommended by SIrs are categorized into two themes, including Enhancing Audience's Comfortability (Theme 1) and Enhancing Interpreter's Comfortability (Theme 2). This means the interpreters used ICC transfers to benefit both their audience and themselves.

Compared with Theme 2, Theme 1 was more commonly observed. It showed up in 22 quotes which were mentioned by all eight interviewees in five out of six questions. Among the seven reasons for SIrs to use ICC transfers, five of them were under this theme. Meanwhile, Theme 2 appeared in 14 quotes, by six interviewees in three questions, and consisted of two reasons. As can be seen, that Theme 1 is more popular shows that though professional interpreters could think for themselves, they always give the highest priority to the audience's benefit. In other words, it is by default that an interpreter has to guarantee that her ${ }^{1}$ audience is happy with the target texts she produced. At certain moments, she could apply certain ICC transfers for her own benefit (mostly to save time and attention resources). This strategic decision and its associated benefits were also enabled by her IC.

\subsection{Specific Findings}

In the FGI, reasons for using ICC transfers are the main level of data analysis. As a

\footnotetext{
${ }^{1}$ The convention in interpreting studies is that interpreters are called "she", while speakers are referred to as "he".
}

consequence, the discussion in this part focuses on the seven reasons identified from the FGI. As mentioned in the previous section, the seven reasons for using ICC transfers are categorized into two themes. Under the first theme "Enhancing Audience's Comfortability", there are five reasons. The common point of these reasons is that they all aim to bring positive experience to the audience. Besides, the underlying basis for these reasons are directly related to the interpreter's IC. In other words, the SIrs make use of their IC to render an optimal target text, in their opinion, to serve the workshop participants who need their interpretation service.

The first reason, R1 - "Accurate comprehension" - was acknowledged by many interpreters (I1, I4, I6, I7, I8) and in different situations (questions 1, 2, 6). This means SIrs always try to make sure the source text messages are conveyed accurately to the audience. Detailed explanations can be found in the following remarks from FGI participants.

- If we don't understand the intention and translate word-for-word 'vấn đề' into 'problem', it's not correct. For example, in "nhưng mà chúng ta cũng hết súc quan tâm đến vấn đề là chúng ta phải kết hợp giữa chiếu sáng tụ nhiên", it refers to "matter" or "point of this", not "problem". (I1, question 2 - "Vấn đề") 
- In case I need to translate that phrase, I tend to use "ladies and gentlemen" or add "so" in the front. I think that phrase is a way of addressing and attracting attention, rather than to "report" or "inform". (I8, question 6 - "Báo cáo")

- If the situation is not relevant to "comrades" but the interpreter still uses "comrades", it is not correct. That interpreter has not worked correctly... To correctly render "dồng chi", we must have a specific situation and identify the speaker's intention first. (I4, question 1 - "Đồng chí")

$\mathrm{R} 1$ rooted from some unique features of Vietnamese culture that may not exist in others. The closely rendered versions of the source texts in many cases possibly do not reflect what the speakers really intend to say. A worse case is that these interpretations may even make the audience feel awkward or confused as the equivalent understanding is missed in the cultures outside Vietnam. For examples, "vấn đề" and "báo cáo" in Vietnamese are often used with meanings far different from "problems" and "report". As pointed out by I1 and echoed by other participants, when it comes to the English version, these source words should be translated by other options that may not look like their dictionary equivalents. Similarly, in a lot of situations, using ICC transfers and translating "đồng chí" into "ladies and gentlemen", "mister", or "madame" would better match the speaker's intention and be more understandable to the audience than using "comrade".

The next reason, R2 - "Lower sensitivity", was also relatively popular. It was suggested by six interviewees (I1, I2, I4, I5, I6, I7) in two situations (question 1 and 3). This reason emerged in relation to the words that are associated with some political meanings.
I will use a neutral word to the audience... To neutralize cultural words or concepts that may sound a bit uncomfortable in some situations and may make the two sides difficult to understand each other... Not to cause unnecessary tension. (I2, question 1 - "Đồng chí")

In this case, "đồng chí" is used quite commonly in a communist society like Vietnam. However, as communism may sometimes be associated with negative meanings in other parts of the world, this way of addressing may sound politically unpleasant to foreigners. Replacing "comrade" by other common addressing devices, or even skipping this word in certain cases could be a better choice.

- The one that is more neutral is "quyền con nguòi"... When mentioning the general, the neutral, people often use "quyền con nguoòi”. (I1, question 3 - "Human rights")

- We were also warned not to use "xã họi dân sụ" but "tổ chức chính trị xã họi or things like that because it is sensitive... This and "human rights" may be similar as they are related to some intercultural or interpolitical differences between the two sides. (I7, question 3 - "Human rights")

Politically, "human rights" translated as "nhân quyền" is also a sensitive topic in the context of Vietnam. This was explicitly mentioned by most FGI participants. "In Vietnam, when mentioning 'nhân quyền', there are some political implications" (I6). "The connotation of 'nhân quyền' in Vietnamese is a bit negative and particularly sensitive in terms of politics" (I2). "Vietnam is too sensitive to this word (nhân quyền)" (I4). That is why many practitioners, often unconsciously using ICC transfers, tend to use "quyền con người”" as a safer alternative. Though "nhân quyền" and "quyền con người" mean denotatively the same, the 
later has been more widely accepted on the official media. Using it could prevent any unnecessary irritation to the ears of the target audience due to "intercultural or interpolitical differences" (I7).

For the next reason of using ICC transfers, interviewees claimed that these strategies may give their interpretation a sense of "Higher universality" (R3). This reason was specifically mentioned in relation to rendering addressing forms.

- In an ordinary conference or workshop about science or a project, there are different groups of participants. It is not necessary to use "comrade" but to use "Mister" or "Miss" or "Mistress". (I1, question 1 - "Đồng chí”)

- When we know who the audience is and I see only Westerners, all instances of "đồng chi" will not be interpreted. For example: if "dồng chi đại sú" is rendered as "comrade ambassador", it is extremely inappropriate. (I7, question 1 - "Đồng chí")

With regards to "đồng chí", sometimes it is used by Vietnamese speakers simply as a way of addressing other people in general - a common practice originated from a communist lifestyle. In many cases, not all the addressees are in the same political party as the speaker. When it comes to the situation of an international workshop, the target users of interpretation service are, of course, foreigners. Few of them are communists.

Under the influence of ICC transfers, using "Mister", "Miss", or "Madame" - English common addressing devices - is suitable to more foreign audience.

Whether "chị" or "bạn" is more appropriate depends on the relation between the "speaker" and the "audience": Do they know each other? Are they so close that "ban" should be used? (I7, question 4 - "You")
The above quote from I7 is another evidence for R3. Addressing the audience as "chị" may be more general regardless of the level of acquaintance between the speaker and the audience.

R4 - "Higher respect" was recognized by two interviewees, relevant to the discussion on addressing devices. Despite its limited prevalence, this reason is inter-culturally important. Accordingly, if the interpreter is more mindful of the intercultural differences between the speaker and the audience, her renditions will show a higher level of respect to the addressee and, hence, be more appreciated.

The word "chi" shows higher respect. Vietnamese and some languages have a principle "xung khiêm hô tôn" (lit. using an inferior term to call oneself and a more respectful term to address others)... So "chi" is neutral, but has a higher level of respect. (I1, question 4 - "You")

I1 is a senior researcher in linguistics, beside his job as a professional interpreter. Therefore, his explanation was both practical and academic. As seen in the quote, interpreting "you" into "chi" was better because it fitted the addressing principle in Vietnamese, providing the addressee a higher status in a discursive encounter.

In some cases, we were reminded absolutely not to use "you", but have to use "Your Royal Highness" or "Your Majesty". (I7, question 4 - "You")

The above quote from 17 was extended from the main FGI topic. When discussing how to deal with the situation given by the researcher, he remembered a similar and interesting case. He was interpreting for a reception dinner hosted by the Government of Vietnam to welcome the Swedish Royal Family. 
In that encounter, the interpreter was constantly reminded to refrain from rendering "ông", "bà" in Vietnamese into "you" in English. Instead, "Your Royal Highness" and "Your Majesty" special forms of addressing must be used to be suitable to the special guests.

Although like the previous one, the fifth reason of R5 - "higher equality" - did not gain the attention of many interviewees, it is explicitly related to intercultural differences. The explanations provided were also extensive and interesting.

Sometimes in Vietnam, the power distance or hierarchy gap is so clear. The inferior wants to show respect and they lower themselves by saying "báo cáo". Meanwhile, equality is more upheld for Westerners. So I think when interpreting into English, we don't need to express that (power distance). It is only important in Vietnamese. (I6, question 6 - "Báo cáo")

In Vietnamese culture, like some other Asian neighbors, social hierarchy is very important. The power distance is materialized in different aspects of the society, including in the way people talk to each other. "Báo cáo" is usually used to mark a conversation between an inferior and a superior. However, Westerners may not care too much for this gap, at least in the way of addressing each other. With ICC transfers, skipping "báo cáo" or replacing it by other more neutral expressions could create a better sense of equality and attain naturalness to English listeners.

The second theme of reasons for using ICC transfers (Enhancing Interpreter's Comfortability) include two items: R6 and R7. These reasons base themselves on the SIr's IC and aim to 'make life easier' for the interpreters without compromising the audience's experience. It should be noted that though 'Efficiency' and 'Authentic Vietnamese preservation' are not directly related to the SIr's intercultural competence, the application of ICC transfers in these situations indeed requires very good knowledge and skills of the involved languages and cultures. For example, to firmly remove unimportant details while doing no harm to the audience's understanding, the interpreters must very quickly consider the intercultural differences between the speaker and the target audience. Only when knowing that the details to be removed do not contribute to the overall source text message can the SIrs proceed with this intended solution. That is why R6 and R7 are counted as reasons for using ICC transfers.

The sixth reason, R6- "Higher efficiency", was actually the most popular among all the seven reasons recorded in the FGI. It was mentioned by six out of eight interviewees (I1, I2, I3, I6, I7, I8) and was relevant to three situations in the FGI (questions 2, 5, 6). Some of the interpreters' quotes were as follows:

- His word indeed is not very meaningful so when providing simultaneous interpretation, if the speaker is too fast and we may have challenges in catching up and assuring accuracy, these words can be omitted... If some words are surely fillers, we can skip them and save time to focus more on the main points. (I2, question 5 - "As you know").

- It is not a phrase with important meanings. If we have time, like the speaker is not too fast, we can render it. But if the speaker is too fast or the information is not too sophisticated or important, we can skip it to save time. (I8, question 5 - "As you know").

- There are two cases for this phrase. In one case, it has a meaning; in another case, it is just a filler. Like in sentence 1, we absolutely neither have to translate nor compensate. We 
can save time and effort and focus on other contents. (I7, question 6 - "Báo cáo").

All of these comments explicitly referred to R6 and provided the logic underlying the reason. Accordingly, most interpreters considered the source texts in these situations only habitual fillers. They did not contain any material meaning or they had some meanings but only recognizable to the SL audience. An effort to fully render them into the TL would not contribute to the understanding of those listening to that language. Therefore, the decision made was to omit these words. This decision, applying an ICC transfer (S4 cross-cultural transfer), gave the interpreters more time and mental resources to spend on the more important details coming from the speaker. The usefulness and practicality of R6 partly explain why it is so popular among the interpreters.

\section{R7 - "Authentic Vietnamese} preservation" is the last reason identified from the FGI regarding why ICC transfers were used (I1 in question 3 ).

In laws, "quyền con ngườ is also used more commonly than "nhân quyền". This is the result of an effort to reserve authentic Vietnamese language: to use purely Vietnamese or highly Vietnamized words. (I1, question 3 - "Human rights")

Again, I1 provided an academic point from his research background. "Quyền con người" is only one third Sino, compared to "nhân quyền" - a purely borrowed word. Using the former would have a positive contribution to Vietnamese culture and language sovereignty. This effort, which is under the impact of ICC transfers, should be appreciated when so many words are borrowed, sometimes carelessly, into Vietnamese.

\section{Conclusion}

From the perspective of professional interpreters, there were seven reasons why ICC transfers were used. Most of these reasons were mentioned by different interpreters and in different situations, which, to some extent, demonstrated their validity. The seven reasons identified are under two themes: Enhancing Audience's Comfortability (Theme 1) and Enhancing Interpreter's Comfortability (Theme 2). This means having IC in general, using ICC transfers in particular, is beneficial not only to the audience, but also to the interpreters themselves. As a matter of fact, the audience's benefits are more frequently observed, meaning they are always the top priority to SIrs.

Another important finding from the FGI is that IC is very important to interpreters. Based on the data collected, it can be seen that all interpreters used ICC transfers in different situations. They considered intercultural differences between the speaker and the target audience even when they decided not to use an ICC transfer or when their decisions were not directly related to IC.

Methodologically, FGI has proved itself as a useful tool for qualitative data collection. The interaction among interviewees provides invaluable information, sometimes even broader than the intended topic.

\section{References}

\section{Vietnamese}

Nguyễn Quang (2014). Các loại chuyển giao trong giao tiếp giao văn hóa. Tạp chi Khoa họ ĐHQGHN: Nghiên cứu Nuớc ngoài, 30(3), 14-22.

\section{English}

Archibald, M. M., Ambagtsheer, R. C., Casey, M. G., \& Lawless, M. (2019). Using Zoom Videoconferencing for Qualitative Data Collection: Perceptions and Experiences of Researchers and Participants. International Journal of Qualitative Methods, 18. 
https://doi.org/10.1177/1609406919874596

Bahumaid, S. (2010). Investigating Cultural Competence in English-Arabic Translator Training Programs. Meta, 55(3), 569-588.

Bloor, M. (2001). Focus groups in social research. London: Sage Publications.

Cohen, L., Manion, L., \& Morrison, K. (2007). Research methods in education. London: Routledge.

Cui, Y., \& Zhao, W. (Eds.). (2014). Handbook of Research on Teaching Methods in Language Translation and Interpretation. Hershey, PA: IGI Global.

Deconinck, J., Humblé, P., Sepp, A., \& Stengers H. (Eds.). (2018). Towards transcultural awareness in translation pedagogy. Berlin/Zürich: LIT Verlag.

Dinçkan, Y. (2010). Culture-Bound Collocations in Bestsellers: A Study of Their Translations from English into Turkish. Meta, 55(3), 456-473. https://doi:10.7202/045065ar

Eyckmans, J. (2017). Cultural competence in translation studies and its assessment. In J. Deconinck, P. Humblé, A. Sepp \& H. Stengers (Eds.), Towards transcultural awareness in translation pedagogy (pp. 209-229). Berlin/Zürich: LIT Verlag.

Fenyo, S. S. (2005). The translator's cultural competence. European Integration Studies, 4(2), 61-72.

Hurtado, A. H., \& Olalla-Soler, C. (2016). Procedures for assessing the acquisition of cultural competence in translator training. The Interpreter and Translator

\section{Appendix}

\section{Appendix title}

Appendix 1: FGI Invitation

Appendix 2: FGI Agenda

Appendix 3: FGI Participant Information

Appendix 4: FGI Questions (ppt file)

Appendix 5: FGI Key Quotes

Appendix 6: FGI Summary with Quotes

Appendix 7: FGI Audio Recordings
Trainer, 10(3), 318-342. https://doi.org/10.1080/175 0399X.2016.1236561

Kaczmarek, L. (2010). Modelling Competence in Community Interpreting: Expectancies, Impressions and Implications for Accreditation. Doctoral Thesis, University of Manchester.

Krueger, R. A., \& Casey, M. A. (2000). Focus groups: A practical guide for applied research. Thousand Oaks, Calif: Sage Publications.

Kvale, S. (1996). Interview Views: An Introduction to Qualitative Research Interviewing. Thousand Oaks, CA: Sage Publications.

Nguyen, N. B. (2020). Reactions of Conference Audience to the Use of Intercultural Communication Transfers by Simultaneous Interpreters. Proceedings of ULIS Conference on Interpreting and Translation. Hanoi, 27 October 2020.

Solovyeva, E., Sabirova, D., \& Morozova, T. (2015). Forming students' linguistic and cultural competence in academic translation and interpretation studies. Procedia - Social and Behavioral Sciences, 199, 415422. https://doi.org/10.1016/j.sbspro.2015.07.527

Yarosh, M. (2015). Translator Intercultural Competence: A Model, Learning Objectives and Level Indicators. In Y. Cui \& W. Zhao (Eds.), Handbook of Research on Teaching Methods in Language Translation and Interpretation (pp. 160-178). Hershey, PA: IGI Global.

\section{Link 1}

bom.to/6gpmjB

bom.to/9fmaHh

bom.to/6hCFFX4

bom.to/ArZUDm

bom.to/JH3gpf

bom.to/qG1IoD

bom.to/NrSW0x

\section{Link 2 (backup)}

bit.ly/33mSUxB

bit.ly/2Ga6EDa

bit.ly/30rtpcG

bit.ly/34dfiIS

bit.ly/36xuK1I

bit.ly/34oIxZw

bit.ly/3joORq6 


\title{
LÝ DO SỬ DỤNG \\ CÁC CHIẾN LƯợC CHUYỄN GIAO LIÊN VĂN HÓA TỬ GÓC NHİN CỦA PHIÊN DỊCH CHUYÊN NGHIỆP
}

\author{
Nguyễn Ninh Bắc
}

Trưòng Đại học Ngoại ngũu - ĐHQGHN

Phạm Văn Đồng, Cầu Giấy, Hà Nội, Việt Nam

Tóm tắt: Nghiên cứu này tìm hiểu lý do sử dụng các chiến lược chuyển giao liên văn hóa (ICC) từ góc nhìn của các phiên dịch chuyên nghiệp. Dựa trên các chiến lược chuyển giao ICC của Nguyễn Quang, nghiên cứu tiến hành một cuộc phỏng vấn nhóm tập trung để thu thập dữ liệu trước khi phân tích dữ liệu theo hướng quy nạp. Có tổng cộng bảy lý do sử dụng các chiến lược chuyển giao ICC, thuộc 2 chủ điểm: Giúp khán giả thoải mái hơn (Chủ điểm 1) và Giúp phiên dịch thoải mái hơn (Chủ điểm 2). Các phát hiện này cho thấy việc sử dụng các chuyển giao ICC nói riêng, việc có năng lực liên văn hóa (IC) nói chung không chỉ mang lại lợi ích cho khán giả, mà còn cho chính phiên dịch viên.

Từ khóa: chuyển giao liên văn hóa, phiên dịch song song, phỏng vấn nhóm tập trung. 